\title{
STUDY OF SOME PREVALENT CUSTOMS AND BELIEFS FOR THE HEALTH AND WELL-BEING OF CHILDREN IN URBAN AREA OF MUMBAI AND RURAL AREA OF THANE DISTRICT
}

\author{
Panchal Sanjay $G^{1}$
}

${ }^{1}$ Assistant Professor, Department of Community Medicine, Seth G. S. Medical College and KEM Hospital.

\section{ABSTRACT}

\section{BACKGROUND}

People living in rural and urban area have their own beliefs and practices concerning health and diseases. Not all customs and beliefs are bad. There are many customs and beliefs during child birth and child hearing practice. This study is an effort to know some prevalent customs and beliefs for the health and well-being of children in urban and rural areas.

\section{OBJECTIVES}

1. To study some prevalent customs and beliefs in urban and rural area.

2. To study impact of wrong customs and beliefs on health as well-being of children.

\section{MATERIALS AND METHODS}

The study is descriptive cross-sectional study conducted in urban area of Mumbai and rural area of Thane District, Maharashtra; 100 families were selected and interviewed using semi-structured open ended questionnaire in urban and rural area. Data was sought on customs and beliefs during delivery, after delivery and health and well-being of children. Chi square test was applied as the test of significance at appropriate places.

\section{RESULTS}

$76.67 \%$ people in rural and $85 \%$ in urban area utilized sterilized instruments for the cutting of cord; as per belief of rural area $13.33 \%$ were burning the placenta and $20 \%$ were burring the placenta to keep evil spirits away, this will in turn increase longevity of child; $96 \%$ of rural and $41 \%$ of urban people were applying kajal to child's eye and most of them had eye infection; $38 \%$ in rural and $22 \%$ in urban were avoiding colostrum to newly born child. Prevalence of giving opium to child in rural area was more (61\%).

\section{KEYWORDS}

Custom, Beliefs.

HOW TO CITE THIS ARTICLE: Sanjay PG. Study of some prevalent customs and beliefs for the health and well-being of children in urban area of Mumbai and rural area of Thane district. J. Evolution Med. Dent. Sci. 2016;5(45):2789-2791, DOI: $10.14260 /$ jemds/2016/651

\section{INTRODUCTION}

There are certain beliefs about every aspect of life. With the passage of one generation to another, these methods of practices and customs are same. Some customs are harmless and some are harmful to health. All people, whether rural or urban have their own beliefs and practices concerning health and disease. Customs factors are deeply involved in all affairs of man including health and sickness. Not all customs and beliefs are bad. Some are based on centuries of trial and error and have positive values, while other may be useless or positively harmful. Information about the factors like customs, cultural moves, habits, beliefs and superstitions is still woefully lacking. Knowledge of the local customs and beliefs is therefore very important for improving the health status of mothers and children. This is part of social paediatrics.

Hence, this study is an effort to know some prevalent customs and beliefs for the health and well-being of children in urban and rural areas. ${ }^{1}$

Financial or Other, Competing Interest: None.

Submission 07-05-2016, Peer Review 19-05-2016,

Acceptance 21-05-2016, Published 03-06-2016.

Corresponding Author:

Dr. Panchal Sanjay G,

11/4 United 14 co-op HSG SOC,

Swamy Nityanand Marg,

Koldongri, Shivaji Chowk

Andheri (E)-400069,

Mumbai.

E-mail:drsanpan@yahoo.co.in,drsangpan@gmail.com

DOI: $10.14260 /$ jemds/2016/651

\section{OBJECTIVE}

a. To study some prevalent customs and beliefs in urban and rural areas.

b. To study impact of wrong customs and beliefs on health and well-being of children.

\section{Study Area}

Urban slums of Mumbai area and rural areas of SakwarThane district.

\section{MATERIALS AND METHODS}

The information was collected from house-to-house survey in both urban and rural areas. The study was done by house-tohouse visits in both rural and urban areas, viz. villages in Sakwar area, Thane, and slums Mumbai city. In all 100 families in urban area and 100 families in rural area were interviewed. The information was mostly obtained from the mothers of the children or any other elderly lady in the family. Structured questionnaire was used after taking consent. The questions were put directly in local language Hindi and Marathi.

\section{Inclusion Criteria}

1. Those who were willing to participate in study, i.e. with their consent.

2. Mother or any other elderly lady in the family.

\section{Exclusion Criteria}

1. Those who were not willing to participate in study. 


\section{DISCUSSION}

The information regarding the instrument used for cutting the cord and disposal of placenta was elicited for 30 children in rural and 8 children in urban areas from the same families.

\begin{tabular}{|c|c|c|c|c|}
\hline & \multicolumn{2}{|c|}{ Rural } & \multicolumn{2}{c|}{ Urban } \\
\hline Instruments used & No & $\mathbf{\%}$ & No & $\mathbf{\%}$ \\
\hline Scissors & 2 & 6.67 & 1 & 12.5 \\
\hline Used/unsterile blade & 4 & 13.33 & 1 & 12.5 \\
\hline New blade & 21 & 70 & 5 & 62.5 \\
\hline Knife & 3 & 10 & 1 & 12.5 \\
\hline Total & $\mathbf{3 0}$ & $\mathbf{1 0 0}$ & $\mathbf{8}$ & $\mathbf{1 0 0}$ \\
\hline $\begin{array}{r}\text { Table I: Showing the Practice of Using Different } \\
\text { Instruments for Cutting the Cord }\end{array}$ \\
\hline
\end{tabular}

From Table I, it is seen that $76.67 \%$ attendants in rural and $85 \%$ in urban area utilized sterilized instrument for cutting the cord. This information was presumed, because these mothers replied that the attendant at the time of birth was a trained person. In the remaining group, the attendants must have been indigenous dai or a relative who used any sharp article like sickle, blade, knife, etc., available at that moment without any idea of asepsis. After serving the cord, a definite practice exists for the disposal of placenta (Table II).

\begin{tabular}{|c|c|c|c|c|}
\hline \multirow{2}{*}{ Method } & \multicolumn{2}{|c|}{ Rural } & \multicolumn{2}{|c|}{ Urban } \\
\hline & No & $\%$ & No & $\%$ \\
\hline 1. Buried & 6 & 20 & 1 & 12.5 \\
\hline 2. Burnt & 4 & 13.33 & - & - \\
\hline 3. Thrown in dust bin/gutter & & & & \\
\hline 4. Information not available & 2 & 6.67 & 1 & 12.5 \\
\hline Total & 30 & 100 & 8 & 100 \\
\hline
\end{tabular}

This practice has come about due to high infant mortality rate prevailing in the earlier days in our country. It is believed that the placenta has an influence on the longevity of the child. Therefore, an effort is made to bury the placenta in the same room in the courtyard, if the floor of the house is pucca. By burial of the placenta in the house, the family was assured that the enemies of the family or the evil spirits were not able to seize the placenta and influence the well-being and longevity of the child. This is a custom which is harmless, aesthetic and sanitary, considering that we have no other adequate system of disposal of refuse in the urban and rural areas. This practice was more common in rural area, where institutional facilities for delivery are limited and people are more orthodox. Similar observation has been reported by Ahluwalia in the Punjab region. ${ }^{2}$

\begin{tabular}{|c|c|c|c|c|}
\hline Practice & \multicolumn{2}{|c|}{ Rural } & \multicolumn{2}{c|}{ Urban } \\
\hline & Yes & No & Yes & No \\
\hline $\begin{array}{c}\text { Observing rituals at the time } \\
\text { of birth and thereafter }\end{array}$ & $94 \%$ & $6 \%$ & $92 \%$ & $8 \%$ \\
\hline $\begin{array}{c}\text { Consulting religion head for } \\
\text { giving name and enquiring } \\
\text { details of significance at the } \\
\text { time of birth }\end{array}$ & $87 \%$ & $13 \%$ & $78 \%$ & $22 \%$ \\
\hline Application of kajal & $96 \%$ & $4 \%$ & $41 \%$ & $59 \%$ \\
\hline $\begin{array}{c}\text { Observing vows for the well- } \\
\text { being and longevity of the } \\
\text { child }\end{array}$ & $46 \%$ & $54 \%$ & $20 \%$ & $80 \%$ \\
\hline
\end{tabular}

\begin{tabular}{|c|c|c|c|c|}
\hline $\begin{array}{c}\text { Applying indigenous } \\
\text { preparations on the fontanelle } \\
\text { of infant }\end{array}$ & $48 \%$ & $52 \%$ & $25 \%$ & $75 \%$ \\
\hline $\begin{array}{c}\text { Started breast feeding } 1 / 2 \mathrm{hr} . \\
\text { after birth. }\end{array}$ & $16 \%$ & $84 \%$ & $58 \%$ & $42 \%$ \\
\hline Avoid Colostrum & $38 \%$ & $62 \%$ & $22 \%$ & $78 \%$ \\
\hline $\begin{array}{c}\text { Tied black thread on } \\
\text { hand/black, dot on head }\end{array}$ & $96 \%$ & $4 \%$ & $98 \%$ & $2 \%$ \\
\hline Oil massage & $96 \%$ & $4 \%$ & $98 \%$ & $2 \%$ \\
\hline $\begin{array}{c}\text { Application of oil in ear, nose } \\
\text { and eyes }\end{array}$ & $54 \%$ & $46 \%$ & $18 \%$ & $82 \%$ \\
\hline $\begin{array}{c}\text { Table III-a: Showing Various Rituals \& Practice Performed } \\
\text { After Birth }\end{array}$ \\
\hline
\end{tabular}

Table III-a shows the practice of observing rituals at the time of birth and thereafter. It is seen that $6 \%$ and $8 \%$ in rural and urban areas respectively represent families, who have more rational progressive outlook. There is unanimity of opinion that with the advancement and development of the country and a rationality of outlook, religious and rituals into the background a similar trend exists. Table III-a showing customs, beliefs and other practices for the health and wellbeing of the children in both areas regarding consultation with religious head in connection with naming the child and details of significance at the time of birth.

From Table III-b, it is seen that $96 \%$ of families in rural and $41 \%$ in urban areas respectively adopt the practice of applying kajal to the baby's eye and other parts. These customs dated back to antiquity evidence for the same can be seen in Charaksanhita. ${ }^{3}$ which reads as follows.

"That for the benefit of the eyes, the kajal should be applied to the eyes to promote the secretions and elimination of foul matter of the eyes." It should be applied on eighth day of every fortnight, i.e. Poornima and amavasya by the sight improves." The practice of application of kajal with unwashed fingers has been blamed for admission of trachoma and other infections. For the prevention of blindness in children, besides other measures suggest that the mothers should wash fingers before applying kajal to the baby. The casual relationship of application of kajal and incidence of eye infection is to be investigated considering the suitable, safe preparation of kajal.

\begin{tabular}{|c|c|c|c|}
\hline $\begin{array}{c}\text { Area with Kajal } \\
\text { Application }\end{array}$ & $\begin{array}{c}\text { Infection } \\
\text { Yes }\end{array}$ & $\begin{array}{c}\text { Infection } \\
\text { No }\end{array}$ & Total \\
\hline Rural & 58 & 38 & 96 \\
\hline Urban & 38 & 03 & 41 \\
\hline Total & $\mathbf{9 6}$ & $\mathbf{1 1}$ & $\mathbf{1 3 7}$ \\
\hline \multicolumn{4}{|c|}{ Table III-b: Showing Effect of Kajal Application on Eye } \\
\hline
\end{tabular}

Chi-square ---16.3 df=1 highly significant.

Another custom which is more prevalent in rural area is giving opium to the children.

\begin{tabular}{|c|c|c|}
\hline & Rural & Urban \\
\hline Opium & $\mathbf{\%}$ & $\mathbf{\%}$ \\
\hline Yes & 61 & 07 \\
\hline No & 39 & 93 \\
\hline \multicolumn{3}{|c|}{ Table IV: Showing use of Opium in Infants } \\
\hline \multicolumn{2}{|c|}{}
\end{tabular}


This was not seen in urban areas. The only reason which was elicited was that child will have better sleep and there will not be any abdominal pain.

\begin{tabular}{|l|c|c|}
\hline & Rural & Urban \\
\hline & $\begin{array}{c}\text { No. of } \\
\text { Patients }\end{array}$ & $\begin{array}{c}\text { No. of } \\
\text { Patients }\end{array}$ \\
\hline $\begin{array}{l}\text { 1. Malnourished } \\
\text { children }\end{array}$ & $45 \%$ & $30 \%$ \\
\hline 2. Eye infection & $58 \%$ & $38 \%$ \\
\hline 3. Ear infection & $43 \%$ & $20 \%$ \\
\hline \multicolumn{2}{|c|}{ Table V: Showing Morbidity Pattern in Children } \\
\hline
\end{tabular}

Table $\mathrm{V}$ shows that $45 \%$ of children in rural areas and $30 \%$ in urban area are malnourished. Number of children with eye and ear infections is seen more in rural areas. This shows that effects among customs, beliefs and practice on child health is more in rural than in urban areas; one of the major cause can be education.

\begin{tabular}{|c|c|c|}
\hline Education & Rural & Urban \\
\hline Literate & $39 \%$ & $58 \%$ \\
\hline Illiterate & $61 \%$ & $42 \%$ \\
\hline \multicolumn{2}{|c|}{ Table VI: Showing Education Status of Mothers } \\
\hline
\end{tabular}

Table VI shows the education status of rural and urban mothers, $61 \%$ of rural mothers, $42 \%$ of urban mothers are illiterate. Only $39 \%$ of rural and $58 \%$ of urban mothers are educated.

Application of indigenous preparation on the anterior fontanelle is the most soft spot of the infant's body and it is imperative that the handling of this spot should be minimized. This part should be protected from excessive changes in temperature, trauma, etc. by application of this preparation. The prescription varies and is dependent on the knowledge of the mother is low or the advice of the religious head or vaidya. The main ingredients of these prescriptions are Kaipal, Ajwain, Bhaga, Camphor, etc., applied in different combinations and permutations. According to their belief, the application of these preparations is advantageous, but it needs investigations whether this practice is harmful or harmless.

\section{SUMMARY}

In this study, an attempt has been made to elicit some of the prevalent customs and beliefs related to child health in rural and urban areas of Mumbai and Thane district. It is observed that definite, well established practices exist in both rural and urban areas. Some of them are harmful like cutting the cord with unsterilized instrument, applying kajal to eyes with unwashed fingers. Some of the practices are age old, having deep rooted human sentiments associated with them, the harmful practices need little modification. A public health worker needs to have some knowledge of these practices to carry out his activities in the area.

\section{REFERENCES}

1. Park K. Textbook of preventive and social medicine. Jabalpur, Bhanot 2000;18 th ed:445-56.

2. Ahluwalia AS. Cultural patterns associated with child birth. Ind Journal public health 1963;7:5.

3. Sharma PV. Charka sanhita 1st ed. Varanasi: chaukhambha orientalia 2005;1:75. 